\title{
Book Reviews: The Hasinais: Southern Caddoans As Seen by the Earliest Europeans
}

Timothy K. Perttula

Heritage Research Center, Stephen F. Austin State University

Follow this and additional works at: https://scholarworks.sfasu.edu/ita

Part of the American Material Culture Commons, Archaeological Anthropology Commons, Environmental Studies Commons, Other American Studies Commons, Other Arts and Humanities Commons, Other History of Art, Architecture, and Archaeology Commons, and the United States History Commons

Tell us how this article helped you.

This Article is brought to you for free and open access by the Center for Regional Heritage Research at SFA ScholarWorks. It has been accepted for inclusion in Index of Texas Archaeology: Open Access Gray Literature from the Lone Star State by an authorized editor of SFA ScholarWorks. For more information, please contact cdsscholarworks@sfasu.edu. 
Book Reviews: The Hasinais: Southern Caddoans As Seen by the Earliest

Europeans

\section{Creative Commons License}

\section{(c) (1) \&}

This work is licensed under a Creative Commons Attribution-NonCommercial 4.0 International License 


\section{Book Reviews}

The Hasinais: Southern Caddoans As Seen by the Earliest Europeans. Herbert Eugene Bolton. University of Oklahoma Press, Norman, 2002. xiv + 194 pp. (paperback edition)

Reviewed by Timothy K. Perttula, Archeological \& Environmental Consultants, LLC

The writing and eventual publication of The Hasinais by Herbert Eugene Bolton, the founder of Spanish borderlands studies, has had a long and storied journey that is well-laid out in an introduction by Russell Magnaghi, the editor of the original 1987 hardback and 2002 paperback editions of the book. Bolton became interested in the Hasinai Caddo peoples of East Texas shortly after he arrived at The University of Texas at Austin in 1901, as he became aware "that American history had always involved the Indians and that, as he began to study southwestern history, he also had to study the ethnology of the region" (p. 5). Through various twists and turns, he had the present book-length manuscript virtually completely written and ready for submittal to the Smithsonian Institution in 1907. Unfortunately, the manuscript was then put aside by Bolton as he moved on to other borderlands historical work on the West Coast and California (p. 13) and he never completed it. Parts of it were used by William J. Griffith, one of Bolton's students, in his 1942 dissertation "The Spanish Occupation of the Hasinai Country, 1690-1737," and then in a later monograph on the Hasinai (Griffith 1954), but it was Russell Magnaghi who took up the task of editing the book manuscript in 1971.

The Hasinai Caddo peoples lived in the Neches and Angelina River basins in East Texas until the late 1830s, and they were a settled and socially complex agricultural folk comprised of at least nine separate groups or tribes linked by kinship ties and shared systems of religion, politics, and ritual. Bolton calls them a confederacy, but that term has little meaning in modern Caddoan studies. Bolton's task in writing the book was to tell the story of what these Caddo people were like at the time of the earliest Europeans, or at least those Europeans (mainly Spanish missionaries) that wrote about the Hasinai groups in the late 17th and early 18th centuries, since Bolton's borderland studies had already impressed upon him that the Hasinai had played an important role (p. 28) in the early history of Texas and Louisiana.

Bolton's book primarily focuses on an ethnographic exploration of the basic character and socio-political organization of the Hasinai groups, emphasizing cultural similarities rather than exploring likely differences in how the nine Hasinai groups lived. He covers in separate chapters their presumed social and political organization; economic life; houses, hardware, and handicrafts; dress and adornment; religious beliefs and customs; and war customs and ceremonials. In so doing, he is able to provide a succinct and readable presentation of the culture of the Hasinai groups as seen through the eyes of various Europeans. As long as the reader realizes that the view provided by Bolton represents a distillation of a mix of reports from the frontier that were written by Europeans with many different agendas - and naturally with little input provided from the Hasinai Caddo themselves - it is still possible to come away from a reading of the book with an important characterization of what the lives and times of the Hasinai Caddo were like some 200-300 years ago. William L. Eakin (1997) provides a more recent historical treatise on the Hasinai in the Bolton tradition; interestingly, Eakin is a student of William J. Griffith, mentioned above. 
Occasionally a bit of archeological evidence on the Caddo works its way into The Hasinais, but usually not to good effect. Bolton links the George C. Davis mound site (41CE19) with the Neches Indians (p. 33), although there is absolutely no evidence of such an affiliation, and Magnaghi calls it an Hasinai site (p. 44). Bolton also mentions the prehistoric Middle Caddoan mounds at the Washington Square site (41NA49) in the modern community of Nacogdoches, Texas, as evidence that Nacogdoches was where the "main village of the Nacogdoche tribe [lived] at the end of the seventeenth century" (p. 35). The available archeological evidence is simply not sufficient to support such ethnic and tribal affiliations. In a discussion of mortuary customs, he mentions the excavation of a Caddo grave in Atlanta, Texas, that was accompanied by the burial of a horse (p. 153). Unfortunately, he does not identify the archeological site that had this burial, and I am unaware of any Caddo burial sites with horse burials other than the Fish Hatchery site near Natchitoches, Louisiana (Walker 1935).

The book manuscript by Bolton on the Hasinai was written almost 100 years ago, and in places it reads like it. For example he describes a Caddo ritual of hunting as "peculiar" (p. 104), their cooking as "crude" (p. 110), their culture "primitive" (p. 138), and their architecture as representing a "middle grade of Indian culture" (p. 111). In a discussion of ornaments, he actually stated that the Hasinai "showed a childish preference for what would jingle and make a noise...this love for ornament was the key to much of the hold acquired by the Spanish and French over the Hasinai natives" (pp. 134-135), and then goes on to state that "No white man ever understood the psychology of an Indian" (p. 138). Nevertheless, and overlooking such unruly tidbits, however, the book still stands as a classic historical and ethnographic study of this aboriginal group. Historians, anthropologists, and archeologists interested in the Caddo Indian peoples would be well served to read this book by Bolton for the first time, if they have not already done so, or to peruse it once again.

\section{REFERENCES CITED}

Eakin, W. L.

1997 The Kingdom of the Tejas: The Hasinai Indians at the Crossroads of Change. Ph.D. dissertation, Department of History, University of Kansas, Lawrence.

Griffith, W. J.

1954 The Hasinai Indians of East Texas as Seen by Europeans, 1687-1772. Philological and Documentary Studies, Vol. 2, No. 3. Middle American Research Institute, Tulane University, New Orleans.

Walker, W. M.

1935 A Caddo Burial Site at Natchitoches, Louisiana. Miscellaneous Collections 94(14). Smithsonian Institution, Washington, D.C. 